\title{
The Effect Spirituality in the Workplace on Organizational Performance with Job Satisfactionas a Moderating Variable In South Sulawesi's Hospital
}

\author{
Kartini Hanafi ${ }^{1}$, Grace T. Pontoh ${ }^{2}$, Eni Novitasari $^{3}$, Endang Sri Ningsih ${ }^{4}$ \\ \{hanafikartini@ rocketmail.com ${ }^{1}$,gracetpontoh@fe.unhas.ac.id ${ }^{2}$, eninovitasariimron06119@gmail.com ${ }^{3}$,end.umsya@gmail.com ${ }^{4}$ \} \\ Faculty of Economics and Business, Hasanuddin University, Makassar, Indonesia. ${ }^{1,2,4}$ \\ Universitas Sulawesi Barat, Mamuju, Indonesia ${ }^{3}$
}

\begin{abstract}
This study aims to determine the impact of the spirituality in workplace on organizational performance with job satisfaction as a moderating variable. This study used a survey method. The research data were analyzed using the Moderating Regression Analaysis (MRA) method. This study provides results that (1) Workplace spirituality (sense of community and meaning at work) has positive and significant impact on the organizational performance, while inner life does not affect organizational performance; (2) job satisfaction does not affect organizational performance; and (3) job satisfaction is able to moderate effect between spirituality in the workplace and organizational performance. The implications of this research expected to provide service organizations, especially in hospitals, to consider conducting training related to spirituality and provide a work environment that can support the spirituality of employees, so the employees can create a comfortable and friendly environment for each others in the organization.
\end{abstract}

Keywords:

The spirituality in workplace, Job Satisfaction and Organizational Performance.

Article Received: 18 October 2020, Revised: 3 November 2020, Accepted: 24 December 2020

\section{Introduction}

In this era where competition is getting tougher, various organizations compete to show maximum their organizational performance. Organizational performance is one of the most important element to assessing how well an organization or management is running an organization's operational activities. The performance measurement that has been carried out by various organizations is by assessing their organization's financial ratios. Unlike other forms of organization, measuring the performance of a hospital as an organization that provides health services must be able to describe the quality of medical services, target strategic goals, efficiency and effectiveness and obtain the desired financial targets[1]And to achieve the desired financial results, hospitals should not only focus on measuring financial performance but also on their non-financial factors. Performance measurement by combining financial and non-financial aspects is known as performance measurement using a balanced scorecard perspective, where performance measurement using the balanced scorecard aspect is a performance measurement that does not only focus on financial indicators, but also on non-financial indicators such as, customer perspectives, internal business processes, and learning and development processes[2]

Some previous researches have found that the balanced scorecard is a managerial tool that defines organizational status and current potential based on specific and targeted goals and measurements ${ }^{[3]}$. Other researches also obtained results that the applications of the balanced scorecard in hospital can be used as an instrument of translator strategy and performance measurement of financial and non-financial terms. Although application of the balanced scorecard to hospitals is not something new anymore, previous research has found no evidence that implementing a balanced scorecard can be one measure in improving hospital performance. It is said that this 
happens because managers failed to understand the causal relationships in the concepts of balanced scorecard ${ }^{[4]}$. However, there are different research results that find that in health care sector, we can benefit from a strategic approach based on implementing a balanced scorecard with indicators targeted for performance improvement, noting that the indicators used can be observed and based on the core values of shared vision of the organization, both at the organizational level and at the system level ${ }^{[5]}$.

In Indonesia alone, in general the health care system still has many vulnerabilities reflected in the lack of organizational performance, which can be seen from the lack of control over special allocation funds provided by the ministry, lack of health care facilities, inadequate medical equipment, lack of incentives finance for doctors, and a weak risk culture. Especially for health services in South Sulawesi, there are problems related to less than optimal health services which have caused the neglect of some patients due to the lack of specialist doctors and also due to the lack of maximum administrative system services that have caused a delay in health services ${ }^{[6]}$. Therefore, related to the problems in the hospital, this study plans to link the variables of spirituality with organizational performance.

Spirituality here concerns the fact that employees have spiritual needs and want to feel the purpose and meaning in their work and the feeling of relating to others and their working community $^{[7]}$. This is because based on the results of previous studies found evidence that spirituality can help organizations maximize profits by fulfilling moral obligations, social services, philanthropic activities and corporate social responsibility ${ }^{[8]}$. This shows that in achieving organizational goals, the organization in this case is not only trying to do everything, good or bad to achieve company goals, but they will try to achieve these goals in a way that is in accordance with the spiritual values in their workplace. The application of spirituality can help employees to improve their performance in order to achieve organizational goals, thus helping companies to increase patient loyalty in this case at the hospital.

Previous research has also noted that there is a positive relationship between spirituality and organizational performance ${ }^{[8][9]}$. Research related to spirituality in the health service sector found that the 3 main dimensions, namely inner life, meaningful work and sense of community influence organizational performance and spirituality can mediate the relationship between work group and organizational performance ${ }^{[10]}$. In contrast to the results of the research that has been done, other studies have found that the sense of community and meaningful work has a positive and significant effect on organizational performance, while inner life has no effect on organizational performance ${ }^{[11]}$.

Another variable that will also be tested in this study is job satisfaction. Job satisfaction plays a very important role in organizational performance because the target and achievement of an organization depends on job satisfaction and in turn contributes to the success and growth of the organization, increases productivity, and improves the quality of work ${ }^{[12]}$. Previous research has also found that organizations with more satisfied employees tend to be more effective than organizations with dissatisfied employees ${ }^{[13]}$. Therefore the purpose of this study was to determine the effect of spirituality in the workplace on organizational performance with job satisfaction as a moderating variable.

\section{Literature Review}

Goal setting theory is one of the theories included in the derivative of cognitive psychology theory, which this theory was first put forward by Locke and Latham in 1990. This theory states that behavior that regulates human consciousness is a goal or in other words it is governed by individual goals. Based on this theory, the principle of action directed at goals is not limited to conscious actions. Not only that, in this theory also stated that as long as someone is committed to the goal, has the ability needed to achieve it, and does not have conflicting goals, there is a positive linear 
relationship between the difficulty of the goal and task performance. This is because the goal refers to valued results in the future, goal setting is the process of creating differences and the most important aspects ${ }^{[14]}$.

Goal Setting theor y is strongly influenced by the assumption that human behavior is driven by social goals and objectives ${ }^{[15]}$. From these results it can be seen that explaining and predicting human performance on several types of tasks and subsequently influences a person's performance by distinguishing them. Another perspective regarding this theory states that introspection alone, the dominant behavioral approach to the notion of motivation gives a limited and doubtful view of human action. Instead, the goal provides a cognitive explanation for motivation ${ }^{[16]}$. Philosophically, goal setting theory is founded on objectivism and especially a collection of rationalists who have their minds, which are governed by their own subconscious thoughts and ideas.

\section{Hypothesis}

Organizational performance has become the most widely discussed topic in the economic and business literature and gaining significant interest from academics and practitioners because it can create competitive advantages for companies and improve their sustainability and future prospects. However, in contrast to company management, public sector organizations have difficulty in measuring the performance of their organizations. This difficulty occurs because institutions engaged in the public sector are more engaged in service delivery, which of course in measuring their performance, cannot be assessed from a financial perspective, but also other aspects besides finance. Therefore, to improve their performance measurement, it is recommended that public sector organizations adopt performance management techniques from the private sector ${ }^{[17]}$.

Some of the studies that have previously been conducted are related to spirituality and organizational performance, as follows:

Table 1.Previous research related to Spirituality in the Workplace and Organizational Performance and Job Satisfaction

\begin{tabular}{|c|c|c|c|}
\hline No & Author & Title & Result \\
\hline 1 & $\begin{array}{l}\text { FranggidaE et al. } \\
\text { (2016) }\end{array}$ & $\begin{array}{l}\text { Effect of Spirituality } \\
\text { Workplace on } \\
\text { Organizational } \\
\text { Commitment and } \\
\text { Job Satisfaction. }\end{array}$ & $\begin{array}{l}\text { - This research find that spirituality } \\
\text { has a positive and significant } \\
\text { relationship to job satisfaction } \\
\text { and organizational commitment. }\end{array}$ \\
\hline 2 & $\begin{array}{l}\text { Gonzales et al. } \\
\text { (2015) }\end{array}$ & $\begin{array}{l}\text { New Evidence of } \\
\text { The Relationship } \\
\text { Between Employee } \\
\text { Satisfaction and } \\
\text { Firm Economic } \\
\text { Performance }\end{array}$ & $\begin{array}{l}\text { - There is positive relationship } \\
\text { between employee satisfaction } \\
\text { and company performance, and } \\
\text { spirituality and financial } \\
\text { performance }\end{array}$ \\
\hline 3 & Bakotic (2016) & $\begin{array}{l}\text { Relationship } \\
\text { Between } \\
\text { Satisfaction } \\
\text { Organizational } \\
\text { Performance }\end{array}$ & $\begin{array}{l}\text { - There is a relationship between } \\
\text { employee job satisfaction and } \\
\text { organizational performance in } \\
\text { both directions,. }\end{array}$ \\
\hline 4 & $\begin{array}{l}\text { Albuquerque } \\
\text { al. (2014) }\end{array}$ & $\begin{array}{l}\text { Primary Health Care } \\
\text { Services: Workplace } \\
\text { Spirituality and }\end{array}$ & $\begin{array}{l}\text { - Spirituality and sense of } \\
\text { community are found in the } \\
\text { relationships between work }\end{array}$ \\
\hline
\end{tabular}


Organizational

Performance

$5 \quad \operatorname{Garg}(2017)$
Workplace

Spirituality

Employee Well-

being: An Empirical

Exploration groups and perceived and objective organizational performance.

- Research found that Spirituality affect organizational performance through normative commitment, affective commitment, ongoing commitment, and employee involvement and work motivation.

Based on the relationship between the concepts and previous research, the conceptual framework used in this study is as follows:

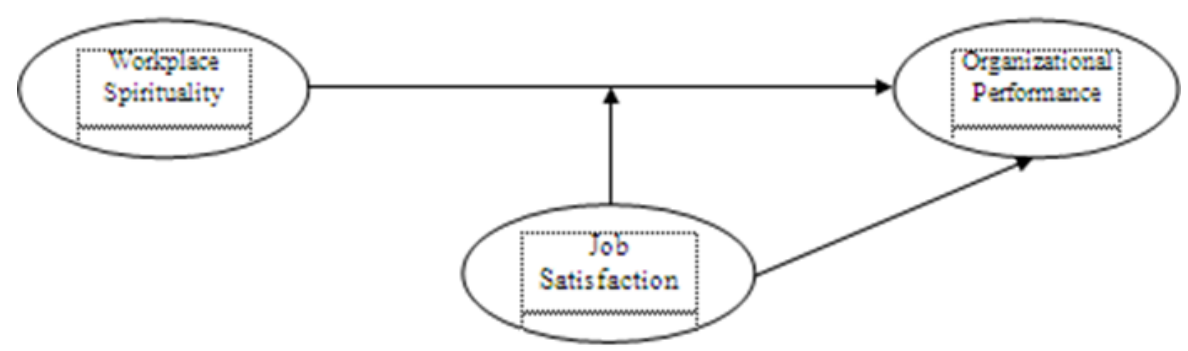

Fig. 1. Conceptual Framework

The last few decades, the theme of spirituality in the business world has attracted attention of academics. This theme was previously considered religious or mystical, but now an integral part of the scope of the organization, spirituality helps employees, managers and leaders find deeper meaning and deeper appreciation of the work they do. Viewed from the point of view of goal setting theory, spirituality in this case is one of the driving factors for a person to maximize his performance. The level of spirituality in the workplace in this case gives someone the stimulation to do their job as well as possible, so as to encourage increased organizational performance. This goal setting theory states the simplest and most direct motivational explanation explains why some people perform better than others because they have different performance goals.

Previous research found that employees who have a higher spirituality in a workplace have better performance than other employees ${ }^{[18]}$. The results of this research are related to the results of other researchers who also found that there was a positive and significant affect between workplace spirituality and organizational performance ${ }^{[8]}$ [19][20]. Based on the correlation of theory and previous researches, the hypotheses to be tested in this study are as follows.

H1: Workplace spirituality has effect on organizational performance.

One of studies conducted that job satisfaction affect organizational performance in both directions, but a fairly weak intensity where the influence of job satisfaction has a greater affect on organizational performance compared to the performance of influential organizations towards job satisfaction ${ }^{[13]}$. These results can be said that job satisfaction determines organizational performance, and not organizational performance that determines employee job satisfaction. Other research also found that there is a direct and positive raffect between employee satisfaction and company performance, and more specific financial performance ${ }^{[21]}$. Based on the results of previous 
studies, the hypotheses to be tested in this study are as follows.

$\mathrm{H}$ 2: Job satisfaction has a positive effect on organizational performance.

Seeing relationship between variables of workplace spirituality, job satisfaction and organizational performance in previous research showed that there is a significant effect between workplace spirituality and employee job satisfaction, and employee job satisfaction affect organizational performance. Not only from the results of previous studies, further hypothesis can drawn based on goal setting theory was explained earlier that the job satisfaction and spirituality are motivational factors that able improve organizational performance. Therefore, the hypotheses to be tested in this research are as follows.

H3 : Workplace spirituality has a positive affect on organizational performance with employee job satisfaction as a moderating variable.

\section{Methodology}

This study uses a quantitative research approach with the nature of correlational research. This research aims to determine the affect of spirituality in the workplace on organizational performance by using a balanced scorecard perspective through variable employee satisfaction. The analysis technique use simple linear regression analysis expressed in a mathematical relationship and to test the moderating relationship will be used Moderating Regression Analaysis (MRA). As well as the unit of analysis used is the organization.

The population in this study is a government hospital. The research respondents were directors, section heads, and section heads. The sample selection technique used is non-probability with sample collection based on criteria (purposive sampling), namely government hospitals type A and B. The type of data used in the study is subjective data and the data sources are primary data sources. The data collection method used is a survey method with data collection techniques using a questionnaire. Furthermore, the personal distribution techniques used are personally administered questionnaires.

Workpalce spirituality variables in this study will be assessed using a questionnaire, which the measurement of workpalce spirituality variables is divided into three parts, namely inner life consisting of five item statements, meaningful work consisting of seven statements, sense of community consists of nine statements ${ }^{[22]}$. The overall item measurement of spirituality variables in the workplace in this study will use a Likert scale from 1 to 5 .

To measure the variable job satisfaction, a questionnaire consisting of 19 statements was used $^{[23]}$. Similar to the previous variables, each item statement in this questionnaire measured by a Likert scale from 1 to 5 . While the instruments related to organizational performance variables will be measured using instruments adopted from previous studies ${ }^{[24]}$. The overall item measurement of organizational performance variables in this study will use a Likert scale from 1 to 5 .

\section{Result}

Before conducting a hypothesis test, we must first conduct a data quality test consisting of reliability testing and data validity. The results of testing the data conducted show that all variables, namely, workplace spirituality, job satisfaction and organizational performance are declared valid. For reliability testing results obtained that spirituality in the workplace obtained a value of 0.870 , job satisfaction obtained a value of 0.646 and organizational performance obtained a result of 0.909 . These results indicate that the overall variables in this study are declared to be real because all variables value greater than 0.60 for cronbach alpha ${ }^{[25]}$.

\section{The affect workplace spirituality on organizational performance}

The results of hypothesis testing obtain that $\mathrm{H}_{1}$ is accepted. This is indicated by a significance value of $0.045<0.05$, so it can be concluded that workplace spirituality measured using the sense of 
community variable has a significant affect on organizational performance. The workplace spirituality that is measured by variables meaning at work has a significant affect on organizational performance. This can be seen from the significance value of $0.006<0.05$. While for workplace spirituality as measured by inner life variables it does not have a significant effect on organizational performance.

The significant influence of sense of community and meaning at work on organizational performance is in line with goal setting theory which has a motivational issue approach from the first level perspective that focuses on the direct level of explanation of individual differences in task performance ${ }^{[14]}$. The theory states that the simplest and most direct motivational explanation explains why some people perform better than others because they have different performance goals. Spirituality in this case is one of the motivational factors that encourages a person to perform better than others, which in the research variables sense of community and meaning at work have a significant influence on organizational performance.

The results of this study are in line with the results of research conducted by previous researchers who found that spirituality at workpace has a positive influence on organizational performance ${ }^{[26][27][10]}$. There is a positive relationship between spirituality in the workplace and organizational performance because spirituality in the workplace enhances the welfare and quality of life of employees, gives employees goals and meaning in the workplace, and provides employees with a sense of relevance to the communities in which they work ${ }^{[27]}$.

\section{The affect of job satisfaction on organizational performance}

The results of hypothesis testing obtain results that $\mathrm{H}_{2}$ is rejected. This is indicated by a significance value of $0.078>0.05$. This shows that job satisfaction does not affect organizational performance. No effect on job satisfaction on organizational performance can explain with goal setting theory, which in this theory states that one's actions are based on the person's goals which in this case job satisfaction does not have synchronization with the level of work difficulty which basically triggers a person to improve his performance.

\section{The affect workplace spirituality on organizational performance with job satisfaction as a moderating}

The results of hypothesis testing showed that $\mathrm{H}_{3}$ was accepted. This result is indicated by a significance value of $0.024<0.05$, so it can be concluded that workplace spiritualityis measured using sense of community has a significant affect on organizational performance with job satisfaction as a moderating variable. The results of hypothesis testing also show that workplace spirituality seen using inner life variables has a significant affect on organizational performance with job satisfaction as a moderating variable. This is seen from the significance value obtained at $0.007<0.05$. This proves that job satisfaction can be used as a variable that can moderate the affect between workplace spirituality and organizational performance. That also means that job satisfaction can improve the affect between workplace spirituality on organizational performance.

The results of other hypothesis tests show that job satisfaction can not moderate the affect between meaning at work and organizational performance where the significance value obtained is $0.825>0.05$. This may be due to organizations such as hospital work that are not only limited to receiving a decent salary but also to a good work environment, which enables employees to carry out their duties to the fullest. Comfort is one of the determinants in increasing organizational performance, because hospitals as one of the organizations that provide health services are very vulnerable to high levels of stress caused by the large number of patients that must be handled and also requires that employees are always at an emotionally stable level. 


\section{Conclusion}

Based on the test results and a discussion of the affect workplace spirituality on organizational performance and job satisfaction as a moderating variable conclude that workplace spirituality which was considered from the aspect of sense of community and meaning at work has positive and significant effect on the organizational performance, while workpalce spirituality which is assessed by aspects of inner life does not have a significant affecton organizational performance. The non-influential aspects of inner life on organizational performance prove that the quality of one's self or lack of spirituality in a person makes employees less dedicated to their work unit. This happens because there is a lack of awareness of someone that what they are doing now will give them a sense of comfort and also be able to draw themselves closer to the God who created them. They do not realize that their excellence at work will be able to provide them with a sense of soul in carrying out their daily activities.

The results of this study also found that job satisfaction dont not have significant affect to organizational performance. This shows that job satisfaction is not the factor that most determines the performance of an organization. This can be explained in goal setting theory which states that organizational performance is determined by the goals of the organization's members. This shows that job satisfaction cannot be affected because it determines the performance of the organization not only employee emotional factors in the organization, such as their job satisfaction, but more towards the employee's final goals which can be external factors such as the work environment and the level of salary they earn and also the workload they receive.

The results of this research also obtained that job satisfaction was able to moderate the effect wokplace spirituality on the organizational performance. These results indicate that job satisfaction is one of the pseudo moderating variables that can be used to improve the effect of workplace spirituality and organizational performance. This result can give an implication to organizations, especially health service organizations such as hospitals to consider conducting training related to spirituality and providing a work environment that can support the spirituality of employees, so as to create a comfortable and friendly environment for every employee in the organization and not only to that extent, organizations especially hospitals should consider the use of performance measurement not only on financial performance, but also focus on measuring performance at the consumer perspective because patients who feel directly the impact of operational activities of the organization are patients.

The limitations of this study are (1) the object of this study limited to regional hospitals in South Sulawesi; (2) the questionnaire used in this study can not be separated from perceptual bias because there is a possibility that respondents did not fill the questionnaire seriously; and (3) the sample used in this study was less than 13 hospitals that were previously targeted because there were several hospitals that did not give research permits due to the reason that the cases studied were not in the hospital, for example in the Dadi General Saki House limiting research only to research relating to psychiatric cases.

\section{References}

[1] Bradea, Ioana and Virginia Mărăcine.: Incidence Between KPIs and Hospital Performance. Grey Systems: Theory and Application Grey. Vol. 5 (2), pp. 234 243 (2015)

[2] Kaplan, R.S., and Norton, D.: The Balanced Scorecard - Measures that Drive Performance. Harvard Business Review. Vol. 83 (7), pp. 71-79 (1992)

[3] Alharbi, Fawaz. Anthony Atkins, Clare Stanier, and Homoud A. Al-Buti.: Strategic Value of Cloud Computing in Healthcare Organisations Using The Balanced Scorecard Approach: A Case Study from A Saudi Hospital. Procedia 
Computer Science 98, pp. 332 - 339 (2016)

[4] Perkins, M., A. Grey and H. Remmers.: What Do We Really Mean By Balanced Scorecard?. International Journal of Productivity and Performance Management. Vol. 63 (2), pp 148-169. (2014)

[5] Porporato, Marcela, Peter Tsasis, Luz Maria, and Marin Vinuesa.: Do Hospital Balanced Scorecard Measures Reflect Cause-Effect Relationships?. International Journal of Productivity and Performance Management, Vol. 66 (3) (2017)

[6] Direktorat Pelayanan Kesehatan.: Laporan Akuntabilitas Kinerja Instansi Pemerintah. Jakarta: Kementrian Kesehtan (2016)

[7] Ashmos, Donde P and Dennis Dunchon.: Spirituality at Work: A Conceptualization and Measure.Journal of Management Inquiry. Vol. 9 (2), pp. 134-145 (2000)

[8] Garg, Naval.: Workplace Spirituality and Employee Well-being: An Empirical Exploration. Journal of Human Values. Vol. 23 (2), pp. 129-147 (2017)

[9] Maleki, M. R., Jafari, H., Safari, H., Khodayari Zarnaq, R.: The Relationship Between Spiritual Leadership and Quality of Work Life in an Iranian EducationalMedical Hospital. Health Information Management (2012)

[10] Albuquerque, Isabel Faro, Raita Campos, Cunha luis Dias, Martins Armando Brito sa.: Primary Health Care Services: Workplace Spirituality and Organizational Performance. of Organizational Change Management, Vol. 27 (1). pp. 59 - 82 (2014)

[11] Novitasari, Eni, Kartini and Grace $T$. Pontoh.: The Relationship Between Workplace Spirituality And Organizational Performance. Journal of Research in Business and Management. Vol. 6(4), pp. 56-63 (2018)

[12] Latif, M. S., Ahmad, M., Qasim, M., Mushtaq, M., Ferdoos, A., and Naeem, H.:
Impact of Employee's Job Satisfaction on Organizational Performance. European Journal of Business and Management. Vol. 7, pp. 166-171 (2015)

[13] Bakotic, Danica: Relationship Between Job Satisfaction and Organisational Performance. Economic Research. Vol. 29 (1), pp. 1-12 (2016)

[14] Locke, Edwin A. and Gary P. Latham..: New Directions in Goal-Setting Theory. Current Directions in Psychological Science. Vo; 15 (5), pp. 265-268 (2006)

[15] Asmus Sven, Florian Karl, Alwine Mohnen, dan Gunther Reinhart.: The Impact of Goal-Setting on Worker Performance-Empirical Evidence from A Real-Effort Production Experiment. Procedia CIRP 26, pp. 127 - 132 (2015)

[16] Neubert, Mitchell J. dan Bruno Dyck.: Developing Sustainable Management Theory: Goal-Setting Theory Based in Virtue. Management Decision. Vol. 54 (2), pp. 304-320 (2016)

[17] Northcott Deryl dan Tuivaiti Ma'amora Taulapapa.: Using the Balanced Scorecard to Manage Performance in Public Sector Organizations. International Journal of Public Sector Management, Vol. 25 (3), pp. 166-191 (2012)

[18] Fry, L., Hannah, S., Noel, M., dan Walumbwa, F.: Impact of Spiritual Leadership on Unit Performance. The Leadership Quarterly Vol. 22 (2), pp. 259270 (2011)

[19] Javanmard, H.: The Impact of Spirituality on Work Performance. Indian Journal of Science and Technology Vol. 5 (1), pp. 1961-1966 (2012)

[20] Malik, M. E., \& Naeem, B.: Role of Spirituality in Job Satisfaction and Organizational Commitment Among Faculty of Institutes of Higher Learning in Pakistan. African Journal of Business Management Vol. 55 (4), pp. 1236-1244 (2011) 
[21] Gonzalez, Santiago Melian,Jacques Bulchand Gidumal, Beatriz Gonzalez Lopez Valcarcel.: New Evidence of The Relationship Between Employee Satisfaction and Firm Economic Performance. Personnel Review. Vol. 44 (6), pp. 906-929 (2015)

[22] Duchon, Dennis and Donde Ashmos Plowman.: Nuturing The Spirit at Work: Impact on Work Unit Performance. The Leadership Quarterly 16, pp. 807-833 (2005)

[23] Mas'ud, Fuad. Survai Diagnosis Organisasional Konsep dan Aplikasi. Semarang: Badan Penerbit Universitas Diponegoro.

[24] Stede, Wim A. Van der., Chee W. Chow, and Thomas W. Lin.: Strategy, Choice of Performance Measures, and Performance. Behavioral Research in Accounting. Vol. 18, pp. 185-205 (2006)

[25] Sekaran, Uma, dan Roger Bougie. 2016. Research Methods for Business Seventh Edition. United Kingdom: John Wiley \& Sons Ltd.

[26] Hong, Y.J.: Identifying Spirituality in Workers: A Strategy for Retention of Community Mental Health Professionals. Journal of Social Service Research Vol. 38, pp. 175-186 (2012)

[27] Karakas, F.: Spirituality and Performance in Organizations: A Literatur Review. Journal of Business Ethics Vol. 94, pp. 89106 (2010) 